\title{
Environmental Management Systems (EMS) implementation processes and practices in European higher education institutions - Top-down versus participatory approaches
}

\author{
Antje Disterheft ${ }^{\mathrm{a}, \mathrm{b}, *}$, Sandra Sofia Ferreira da Silva Caeiro ${ }^{\mathrm{a}, \mathrm{c}}$, Maria Rosário Ramos ${ }^{\mathrm{a}, \mathrm{d}}$, \\ Ulisses Manuel de Miranda Azeiteiro ${ }^{\mathrm{a}, \mathrm{b}}$ \\ ${ }^{a}$ Universidade Aberta, Departament of Science and Technology, Rua da Escola Politécnica 141, 1269-001 Lisboa, Portugal \\ ${ }^{\mathrm{b}}$ Centre for Functional Ecology (CFE), Universidade de Coimbra, 3001-401 Coimbra, Portugal \\ ${ }^{c}$ CENSE - Center for Environmental and Sustainability Research, Faculty of Science and Technology, Universidade Nova de Lisboa, 2829-516 Caparica, Portugal \\ ${ }^{\mathrm{d}}$ CMAF - Center of Mathematics and Fundamental Applications, University of Lisbon, Avenida Professor Gama Pinto 2, 1649-003 Lisboa, Portugal
}

\section{A R T I C L E I N F O}

\section{Article history:}

Received 24 June 2011

Received in revised form

19 November 2011

Accepted 23 February 2012

Available online 7 March 2012

\section{Keywords:}

Sustainable development

Higher education

Universities

Campus sustainability

Environmental Management Systems

Public participation

\begin{abstract}
A B S T R A C T
Environmental Management Systems (EMS) have been implemented on a large scale to improve companies' environmental performance and to certify their achievements. More recently, universities are following this trend, which has been brought forward by the debate about campus sustainability. This empirical international research investigates EMS development and implementation processes in universities around Europe, providing an overview about European higher education institutions with EMS implemented at their campuses, and focuses on a comparison of top-down versus participatory implementation approaches. In addition to regional differences, this article discusses in which aspects an EMS at the campus can be seen as a tool that goes beyond operational aspects to tackle campus sustainability. Furthermore, it provides implications for the professional practice.
\end{abstract}

(c) 2012 Elsevier Ltd. All rights reserved.

\section{Introduction}

An increasing number of companies and institutions have become aware of their environmental impact, together with their social and environmental responsibilities. Environmental Management Systems (EMS) have been implemented on a large scale to improve companies' environmental performance and to certify their achievements. Although these tools have primarily been used by industries and corporations in the private sector, more recently organizations in the public sector and educational institutions such as universities have begun to use this certification process as well. They aim to reduce their environmental impact and, with special regard to universities, to embrace the 'environmental imperative', as named by several authors, and to integrate systemically sustainability into higher education institutions

\footnotetext{
* Corresponding author. Universidade Aberta, Departament of Science and Technology, Rua da Escola Politécnica 141, 1269-001 Lisboa, Portugal. Tel.: +351 922125358.

E-mail address: antje.disterheft@gmail.com (A. Disterheft).
}

(Adomssent et al., 2008; Cortese, 2003; Hansen and Lehmann, 2006; Lozano, 2006; Sharp, 2002; Weenen van, 2000).

In light of the complex challenges today's world is confronted with, universities have been attributed a twofold mission: Firstly, universities are called on to reduce their environmental impact as operating institutions, caused through direct activities, e.g. the use of classrooms and laboratories for teaching and research, offices and catering within the provision of management, administration and support services, and indirect actions, e.g. commuting and consumption of food and drink by the university's community. Secondly, they are called up to carry out research and teaching in the field of sustainability, and on creating settings that allow students and staff to develop new competencies that lead to more sustainable practices and finally to a more sustainable society (Alshuwaikait and Abubakar, 2008).

Campus sustainability links both - the operational aspects of teaching, research and institutional administration, like reducing energy consumption, emissions, materials, waste, and improvement of waste management, - as well as the educational aspect of teaching sustainability and providing opportunities to its internal and external community to learn, to reflect and to develop new 
practices and life style concepts that take into account the wellbeing of current and future generations. According to Cortese (2003), a university system consists of four dimensions, namely Education, Research, University Operations and External Community, which often have been seen as separate, based on hierarchical and competitive structures. But in order to develop a vision for a sustainable campus, he argues that it is necessary to understand the interdependence among these dimensions and to increase the collaboration between them, "as all parts are critical to achieving a transformative change (ibid.) Lozano (2006) adds a fifth dimension of "Assessment and Reporting" that should be considered in an ongoing manner. Departing from the point of view that EMS at the campus can have an impact on any of the dimensions described above, the paper aims to investigate aspects beyond the operational dimension to which EMS are usually connected because of their focus on quantitative measurements of environmental performance. Case studies (e.g. Ferreira et al., 2006; Nicolaides, 2006 and Sammalisto and Brorson, 2008) show that EMS at the campus can be used in a broader sense beyond campus operations, blending also the dimensions of education, research, relationship with stakeholders identified by Cortese (2003) as well the continuous strive for improvement through assessment and reporting, identified by Lozano (2006). However, EMS at the campus are still a relatively sparsely chosen initiative in spite of the positive examples listed above. Concrete numbers are unknown since neither a national nor global register exists. Due to the specific structures and characteristics of higher education institutions it may even be questionable if EMS at the campus indeed successfully work, when looking at studies about barriers to campus greening (e.g. Dahle and Neumayer, 2001; Lozano, 2006). Therefore, this research was motivated by the interest to find out concrete numbers of existing EMS at the campus, the drivers for their implementation and to compare top-down versus participatory implementation approaches that would allow discussing their impact on the five dimensions of a university system described above. It was chosen to focus on the European academic landscape only, in order to be able to make a more profound comparison of regional differences than it would have been on a global scale.

The research objectives led to the following main research questions:

(1) What is the current state of EMS implementation processes and practices at European universities?

(2) Which are the main drivers to implement an EMS?

(3) How have the EMS been implemented and how have students and staff been involved in the process?

(4) Which measurement and reporting tools have been used?

(5) How can these processes and practices be developed further and which implications exist for the professional practice?

Besides regional differences, this article discusses if an EMS at the campus can be seen as one tool beyond operational aspects to tackle campus sustainability, and provides implications for the professional practice. The results of this study shall contribute to the discussion about how sustainable development can be integrated in higher education institutions and specifically how EMS can improve campus sustainability.

\subsection{Sustainable development and the role of universities}

Due to their high societal impact, universities are challenged to take a leadership role in sustainability issues. As universities educate the next generation of decision-makers and influencers, universities can have a vastly greater impact on sustainable development than any other single sector of society (Chambers, 2009).

The debate about campus sustainability has grown over the last three decades. Several international conferences and declarations are proof of this growth (e.g. The Stockholm Declaration (UNEP, 1972), the UNESCO conference in Tbilisi, Georgia (1977) (UNESCO, 1977); the Talloires Declaration (1990) (ULSF, 2008), the Earth Summit (1992) in Rio de Janeiro and the Agenda 21 with its chapters 35 and 36 (UNCED, 1992), the "Copernicus Charter" (1993) (Copernicus Alliance, 2010)). These have all been significant steps in spreading the discussion about the role of universities as multipliers for sustainable development and how the objective of integrating campus sustainability can be approached (Chambers, 2009; Cortese, 2003; Nicolaides, 2006). They led to an increasing number of campus initiatives in this field that also got promoted by the Decade of Education for Sustainable Development 2005-2014, proclaimed by the UNESCO (UNESCO, 2010).

Three stages of sustainability implementation at a university have been identified (Leal Filho, 2009): Stage 1, in which the principles of sustainable development are not integrally understood and no strong efforts were undertaken yet towards promoting sustainability at the institution; systematic projects or a holistic approach are still lacking; Stage 2, in which significant efforts towards sustainable campus operations have been realized, the principles of sustainable development are broadly understood and projects exist to promote sustainability as a whole or in the context of specific subjects and/or research; Stage 3, in which the university has fulfilled the requirements of the previous stages and has a long-term commitment towards contributing to sustainable development, e.g. by means of sustainability policies, and/or by means of certification (ISO 14001 or EMAS), and by means of the existence of senior staff members in charge of the coordination of sustainability efforts and projects. EMS can therefore be seen as a proof of an institution's process in following sustainable principles, and as a sign of the institution's orientation towards incorporating sustainability at an advanced level.

\subsection{Public participation}

Promoting sustainable development is closely linked to the field of public participation and citizen involvement. Participation and empowerment are two terms associated with the development of key competencies for sustainable development. The first term means that "individuals must be provided with numerous opportunities throughout their lives to acquire the information and skills necessary to enact the citizen role" (Howell et al., 1987); the second describes a multidimensional process of learning to think critically and to effect change in the personal life and in the community. Particularly the latter aspect calls on citizens to be personally involved in the decision processes (Florin and Wandersman, 1990).

Agenda 21 stresses the importance of public participation as a "fundamental pre-requisite for the achievement of sustainable development" (UNCED, 1992). The governance strategy "Citizens as partners" of the OECD countries and the Aarhus Convention, approved by the United Nations Economic Commission for Europe in 1998 are aligned with this approach (OECD, 2001; UNECE, 2001).

Regarding the link between sustainable development and public participation, several advantageous aspects have been identified (Meadowcroft, 2004): (i) reconcile and redefine individuals' and groups' interests, (ii) contribute to shaping the future and (iii) adjust to impending change. Furthermore in terms of normative values and learning, participation allows (iv) facilitating a more complete disclosure of existing attitudes, (v) juxtaposing different approaches, (vi) promoting the integration of knowledge and the adaptation of governance to cross-cutting contexts relevant to 
sustainable development, (vii) promoting adaptive management and knowledge acquisition by societal partners and government.

The International Association for Public Participation (2007) divides public participation into five levels, in which the public impact and level of participation increase when activities or methods are directed towards involvement and empowerment (Fig. 1). The effectiveness of empowerment has been studied within several contexts and its positive impacts have been proven empirically (Conger and Kanungo, 1988; Holyoak, 2001). Meanwhile it has also linked to the future employability of the higher education students, since empowerment enhances the students' so called self-skills, such as self-motivation, self-confidence and self-management, but also other recognized abilities like critical thinking, continuous learning, curiosity, developing ideas, taking initiatives, adapting to work culture and developing it further (Harvey, 2000).

Applied to the university context, participation refers to students', faculty and staff involvement, giving the institutional community the opportunity to put into practice sustainability principles at a meso and micro level, e.g. in their academic, personal and professional life, and to be engaged in institutional change processes.

\section{Environmental Management Systems (EMS) in the university context}

EMS can be divided into formal and non-formal standards (Simkins and Nolan, 2004). The two international and best known formal environmental standards are ISO 14001 from the International Standardization Organization, and EMAS (Eco-Management and Audit Scheme), developed by the European Union. These offer the possibility to get a final certification and differ from the nonformal standards, such as EcoCampus to give an example of an EMS found at many British higher education institutions, and which usually are not internationally certified (ibid). Since the launch of ISO 14001 and EMAS in the 90s, the numbers of sites and organizations certified with a formal EMS have been increasing. According to the ISO Survey 2009 (ISO Central Secretariat, 2011), in Europe there are 89237 ISO 14001 certified sites; the highest number of ISO 14001 certifications are in Spain (16527), Italy (14542) and in the United Kingdom (10912). The numbers for EMAS registration are considerably lower: By the end of June 2011, there were in total 4615 organisations and 8011 sites registered (European Comission, 2011a), with most registrations in Germany (1903 sites and 1,393 organisations), followed by Spain (1,635 sites

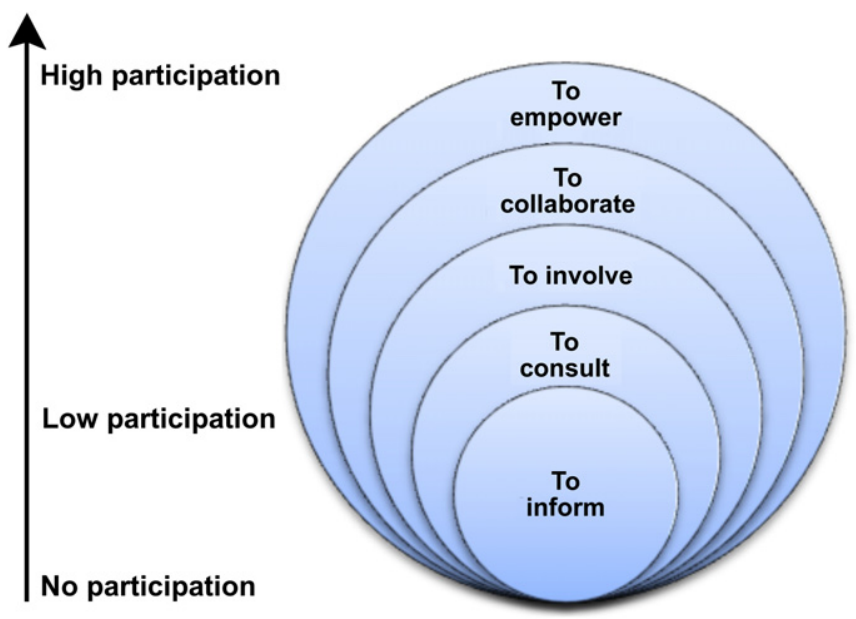

Fig. 1. Level of participation related to the spectrum of participation (adapted from International Association for Public Participation, 2007). and 1,262 organisations) and Italy (1628 sites and 1126 organisations) (European Comission, 2011b).

Maelardalen University (Sweden) and University of Zittau/ Goerlitz (Germany) were the first universities in Europe with a certified EMS: the Swedish institution implemented ISO 14001, the German university implemented EMAS, both received certification in 1999 (Delakowitz and Hoffmann, 2000; Oelreich, 2004).

The "Lueneburg approach" (Adomssent et al., 2008) is one of the first examples in European universities to integrate systemically sustainable development in the whole institution, where the implementation of an EMS at the campus is one tool within the overall approach. Another interesting example is the first ZeroEmission-Campus in Europe (Helling and Cosack, 2007): The Environmental Campus Birkenfeld of University of Applied Sciences Trier, Germany, follows a zero-emission-concept and integrates the implementation of EMAS, which is currently in process. Also this example depicts an integrated approach for campus sustainability, with the EMS being one component, together with sustainability teaching, building management and further institutional initiatives in the overall strategy to achieve a zero-emission campus.

Ferreira et al. (2006) see within the implementation of an EMS "a golden opportunity to develop theoretical and practical work and (...) to foster participation". Some advantages they point out are "new opportunities to improve curricula contents and (...) new examples and 'hands-on' opportunities to push forward research and educational aspects of environmental matters".

Some authors request a campus-specific EMS, as universities are perceived to be more complex than industries, enterprises or private sector corporations and to have different direct and indirect interactions with the environment, mainly with regard to the input and output emissions. Industries and private sector corporations often indicate cost savings, optimized management processes and marketing benefits of a "green" image as the main advantages of pursuing an EMS (Clarke and Kouri, 2009). According to a study about drivers for campus EMS (Bennet and James, 1999), the first generation drivers focus on cost savings and compliance with law and are similar to the drivers companies specify; the second generation drivers focus on stakeholder management, quality management and pollution prevention; and the third generation drivers focus on stakeholder partnerships, sustainable development and life-cycle management. The third generation drivers underline the institution's role as a leader, as a 'good citizen' and emphasize its function of providing best-practice examples Bennet and James, 1999.

It has been thoroughly discussed as to how to move campus sustainability forward (Čiegis and Gineitiene, 2006; Cortese, 1999; Koester et al., 2006; Lozano Garcia et al., 2006), and some authors compare different EMS models (Alshuwaikait and Abubakar, 2008) and discuss their adequacy for higher education institutions (Clarke and Kouri, 2009). Studies were published about EMS in universities at the national level (e.g. Australia (Zutshi and Sohal, 2005), Canada (Bakker, 1998), Sweden (Arvidsson, 2004), United Kingdom (Simkins and Nolan, 2004), USA (Savely et al., 2007)), and many universities report about their experience with EMS in case study articles (Carreiras et al., 2006; Delakowitz and Hoffmann, 2000; Evangelinos et al., 2009; Ferrer-Balas et al., 2009.; Lukman and Glavic, 2007; Noeke, 2000; Oelreich, 2004; Viebahn, 2002). An investigation on a European level has been lacking, and this research aims to contribute to reducing this gap.

\section{Methodology}

The research is based on a combination of qualitative and quantitative methods, using a deep literature review and an internet-mediated questionnaire of a cross-sectional survey design (Fowler, 2002; Tashakkori and Teddlie, 1998). 
The data were gathered in two stages: The first data compilation consisted of a search for European universities with an EMS at the campus (formal and/or non-formal standards), examining the existing literature in scientific journals, books, case studies and websites. A database was set up to collect relevant data, namely (i) university profile (institution's name, location, institution's size (number of students enrolled)); (ii) the EMS type implemented at the campus; (iii) contact persons (environmental officers, sustainability coordinators, researchers, etc). This compilation provided an overview of European universities with an EMS at the campus and permitted an analysis of the distribution of respective EMS types and the relation to the university profile. The second data compilation was based on an internet-mediated questionnaire, administered to environmental coordinators, sustainability officers, researchers or respective personnel in charge of the EMS at the campus which had been identified at the first stage. The questionnaire was comprised of six sections: The first section gathered data about the university profile and EMS type implemented (in order to validate or to complete the previously collected data); the second section investigated the motivation to implement an EMS. The participants could classify five drivers that led to the decision to implement an EMS at the campus on a scale from 1 (not important at all) to 5 (very important). The drivers to classify were (i) Financial support; (ii) Research interests; (iii) Reduce institutional consumption patterns; (iv) 'Greening' the institution's image; (v) Social and environmental awareness/responsibility. Further reasons/motivations could be added in an open text field. The next section explored the implementation approach (top-down or participatory) and, in particular, activities or methods of student and staff involvement at different participation level applied within the EMS implementation process. In the following section it was asked about which measurement and reporting tools had been used, giving the participants the options to indicate specific types of audits, and/or sustainability reports (that follow the Global Reporting Initiative(GRI) guidelines or not), and/or other measurement tools. The questionnaire ended with an open text field for further comments.

In order to measure the institution's participatory performance, a five-level evaluation scale for participatory performance, based on the spectrum of public participation by IAP2 (Fig. 1), was developed. In concrete, the different types of activities that the university had indicated to perform at each participation level were counted and attributed weighted scores: Activities and techniques that allow the public to get involved and to collaborate were considered to be on a higher participation level than passive techniques. This perception was reflected in our evaluation by scoring activities at an up-scale participation level higher than those of the first and second level: A simple weight was associated for participation level 1 (to inform) and 2 (to consult), a triple weight for participation level 3 (to involve), and the last two levels (to collaborate and to empower) with a four and five times weighted factor. The data were normalised into a 0-100 scale, identifying five degrees of participation.

The statistical analysis focused mainly on the identification of the existence and assessment of an association or correlation between items. We looked for differences and trends associated with the institution's characteristics, attitudes and practices. Statistical tests were chosen according to the type of variables (response scales) and the most important were Chi-square test, the coefficient Cramer's V for nominal variables and the coefficients Kendall-tau $\mathrm{b}_{\mathrm{b}}$ and Spearman for nominal/ordinal variables (Hill and Hill, 2009). All the descriptive and inferential statistical analyses were conducted through Microsoft Excel and SPSS 18.0 (Statistical Package for Social Sciences) software. Geographical maps were produced using Stepmap software.

The research area was restricted to member-states of the European Union; however, one institution from Norway and two institutions from Switzerland were included, as the data were of interest for the research topic.

In order to identify geographical characteristics, the European countries in this study were divided into the sub regions Northern, Southern, Western and Eastern Europe, according to the UN Geoscheme (United Nations Statistic Division, 2010).

\section{Results}

\subsection{Overview of European universities with an EMS at the campus}

In total, 47 universities in Europe were identified to pursue an EMS at the campus. The questionnaire was administered to these institutions and 35 institutions responded to the survey (response rate of $74.5 \%$ ).

This section gives an overview about the total number of higher education institutions with an EMS, the universities' profile and the geographical distribution of the different EMS types implemented (first data compilation, $N=47$ ). The results presented in the Sections 4.2 and 4.3 constitute the analysis of the second data compilation and refer to the survey responses $(N=35)$.

The 47 universities identified with an EMS were from 14 different countries (Fig. 2 and Table 1). Germany was the country with the highest number of campuses' EMS (17 institutions, 36.2\%), followed by Sweden and the United Kingdom (seven institutions, $14.9 \%$, and six institutions, $12.8 \%$, respectively).

EMAS was mainly implemented in institutions with less than 10,000 students (58.8\%), whereas ISO 14001 was equally distributed in small, medium and larger institutions (31.3\%; 31.3\%; 37.5\% respectively) (Table 2). It is remarkable that six institutions had more than one system implemented: one university combined ISO 14001 with a non-formal EMS and five had implemented ISO 14001 and EMAS.

EMAS and ISO 14001 are the most frequently implemented systems. It is interesting to see that ISO 14001 is more represented in Northern Europe, 22.6\% (12 institutions), whereas EMAS is more dominant in Western Europe, 28.3\% (15 institutions) (Fig. 3). Nonformal EMS are relatively equally distributed among the European regions.

\subsection{Drivers for EMS implementation}

"Social and environmental awareness/responsibility" was on average considered to be the most important driver to implement an EMS. 80\% of the universities in this study considered this driver to be important/very important. "Financial support", in contrast, was on average considered to be the least important driver and was evaluated differently according to the geographical region: While the Northern and Western European universities (49\%) did not consider this driver as important, higher education institutions in Southern and Eastern Europe evaluated this driver as important or even very important (43\%).

Moderate correlations could be confirmed between the drivers "Greening the institution's image" and "Social and environmental awareness" ( $\tau=0,48$ and $\rho=0,51 ; p$-value $<0.01)$ as well as between "Reduce institutional consumption patterns" and "Social and environmental awareness" ( $\tau=0.45$ and $\rho=0.51 ; p$-value $<0.01$ ). Relating the drivers to the different EMS types, a moderate relationship could be observed between the driver "Reduce institutional consumption patterns" and ISO 14001 as well as EMAS (Cr V $=0.48$ and $\mathrm{Cr} \mathrm{V}=0.47$ respectively, $p$-value $<0.10$ ). The driver "Greening the institution's image" was more associated with ISO 14001 than to other types of EMS ( $\mathrm{Cr} \mathrm{V}=0.48$; $p$-value $<0.05)$. 


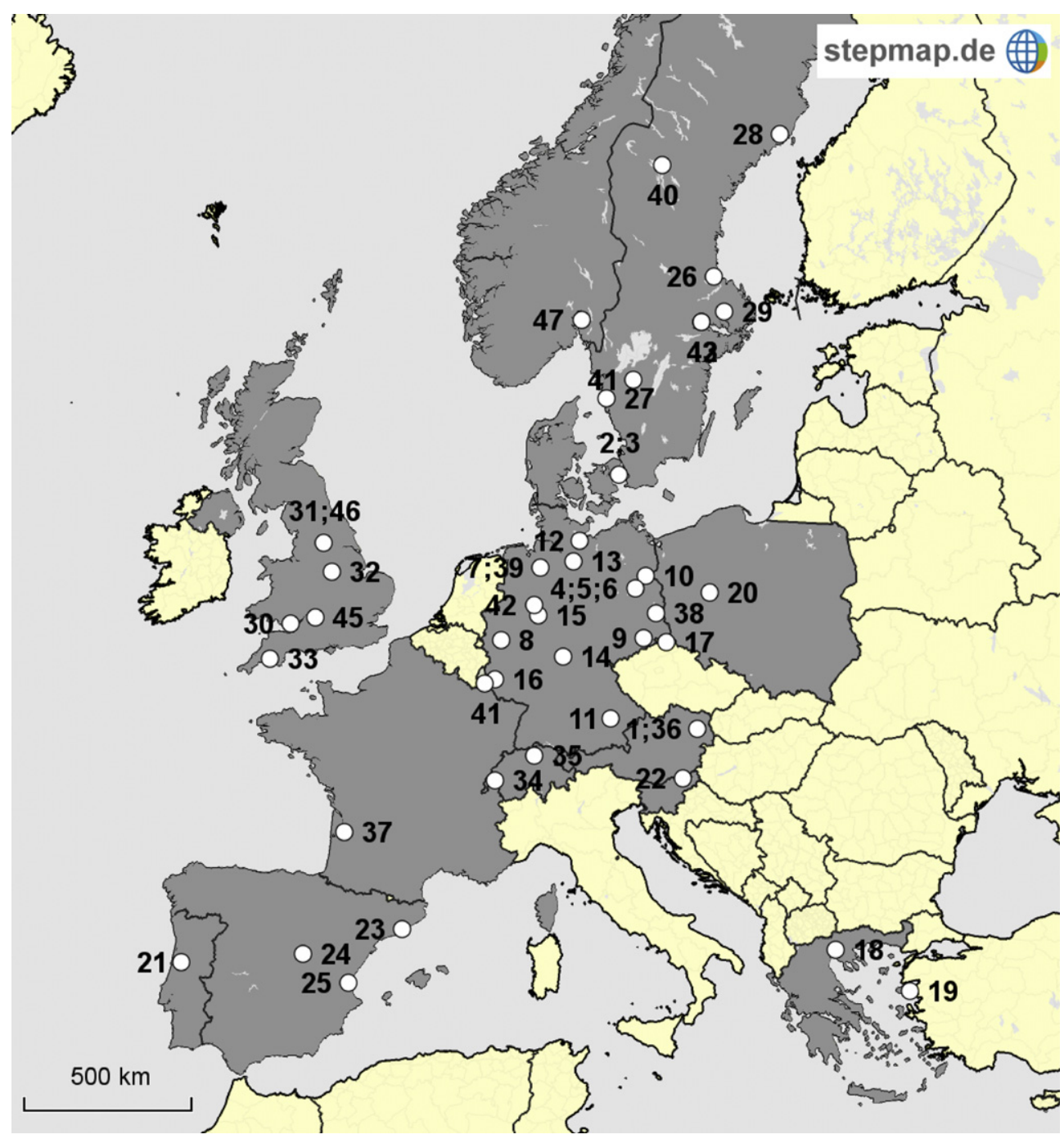

Fig. 2. European Universities with an EMS at the campus (grey colour refers to countries with the 47 institutions identified (white bullets); see also Table 1).

\subsection{Top-down versus participatory approaches}

$60 \%$ of the universities declared to have implemented the EMS by a participatory approach; $20 \%$ indicated to have followed a mix of top-down and participatory approaches and $17 \%$ opted for a topdown approach. One institution did not respond to this question.

The institutions that followed a participatory approach mainly implemented EMAS (64\%), whereas the institutions that executed a top-down approach predominantly implemented ISO 14001 (71\%). The institutions that followed a mix of both approaches opted preferably for ISO 14001 (63\%) or for a non-formal EMS (25\%) (Fig. 4).

Activities and methodologies applied within the implementation process were related to the respective approach (participatory or top-down) (Fig. 5). Respondents could give multiple answers for a range of activities and methods referring to each participation level. The most frequently indicated methodologies within an EMS implementation process were surveys and questionnaires, followed by special training. The website was the most often indicated medium to inform of the implementation process. Online platforms and open forums were found to be the least chosen methodologies. Six universities that had declared to follow a top-down approach, applied also interactive methods, e.g. special training or workshops.

Applying an evaluation scale for participatory performance (described in Section 3 Methodology) on the results of Fig. 5, eight universities (27\%) were attributed an intermediate degree of participation, 14 institutions (47\%) received a high degree of participation and four universities (13.3\%) were awarded a very high degree of participation. ${ }^{1}$ The universities in this study with a high degree of participation or above have mainly implemented EMAS, but it is important to point out that also universities with ISO 14001 or a non-formal system achieved a high degree of participation (Fig. 6). The level of association between the degree of participation and the type of EMS, however, is moderate and statistically significant $(\mathrm{Cr} \mathrm{V}=0.56 ; p<0.05)$.

\subsection{Measurement and reporting tools}

The most frequently applied tools to measure or to report about the university's sustainability achievements were indicated to be regular internal audits (60\%) and specific audits within the EMS

\footnotetext{
1 This calculation was applicable to 30 cases only. Cases with missing data had the following characteristics: (i) At the time of this study, the institution was in an implementation process at an early stage; (ii) the universities did not provide any information on activities or methodologies even though having indicated to follow a participatory or a mix of both approaches; (iii) from the literature review we know that some activities within a participatory approach have been executed but have not been indicated in the questionnaire.
} 
Table 1

European Universities with an EMS at the campus - University name, EMS type implemented and implementation approach (additional info to Fig. 2).

\begin{tabular}{|c|c|c|c|c|}
\hline $\mathrm{Nr}$. & Country & Name & EMS & Implementation approach \\
\hline 1 & Austria & Austrian Marketing University of Applied Sciences & ISO $14001+$ EMAS & $\mathrm{PA}^{\mathrm{a}}$ \\
\hline 36 & & University of Natural Resources and Life Sciences, Vienna & EMAS & $\mathrm{n} / \mathrm{a}$ \\
\hline 2 & Denmark & Aalborg University & ISO 14001 & Mix of TDA ${ }^{\mathrm{b}}$ and PA \\
\hline 3 & & University of Copenhagen & Energy management & Mix of TDA and PA \\
\hline 4 & Germany & Freie Universitaet Berlin & ISO 14001 & Mix of TDA and PA \\
\hline 5 & & Berlin School of Economics and Law & ISO 14001 & PA \\
\hline 6 & & Technische Universitaet Berlin/Max-Volmer-Institut & EMAS & PA \\
\hline 7 & & University of Bremen & EMAS & PA \\
\hline 8 & & University of applied sciences Cologne & ISO 14001 + EMAS & PA \\
\hline 9 & & Technical University Dresden & EMAS & PA \\
\hline 10 & & University of Applied Sciences Eberswalde & EMAS & PA \\
\hline 11 & & University of Applied Sciences Landshut & EMAS & PA \\
\hline 12 & & University of Applied Sciences Luebeck & EMAS & PA \\
\hline 13 & & Leuphana University Lueneburg & EMAS & PA \\
\hline 14 & & University of Osnabrueck & Similar to EMAS & PA \\
\hline 15 & & University of Paderborn & EMAS & PA \\
\hline 16 & & University of Applied Sciences Trier & EMAS (in process) & PA \\
\hline 17 & & University of applied Sciences Zittau/Goerlitz & EMAS & PA \\
\hline 38 & & University of Bielefeld & ISO 14001 & $\mathrm{n} / \mathrm{a}$ \\
\hline 39 & & University of applied sciences Bremen & EMAS & $\mathrm{n} / \mathrm{a}$ \\
\hline 40 & & Brandenburg University of Technology Cottbus & EMAS & $\mathrm{n} / \mathrm{a}$ \\
\hline 18 & Greece & University of Macedonia & EMAS & PA \\
\hline 19 & & University of the Aegan & ISO 14001 + EMAS & PA \\
\hline 20 & Poland & University of Economics Poznan & EMAS & TDA \\
\hline 21 & Portugal & IPC - Politechnic Institute of Coimbra, ESAC & EMAS (suspended) & PA \\
\hline 22 & Slovenia & University of Maribor & Life Cycle Assessment & PA \\
\hline 23 & Spain & Barcelona Tech (UPC) & ISO 14001 in process & TDA \\
\hline 24 & & UAM - Autonomous University of Madrid & Oficina Ecocampus & PA \\
\hline 25 & & UPV - Polytechnical University Valencia & ISO 14001 + EMAS & PA \\
\hline 26 & Sweden & University of Gävle & ISO14001 & Mix of TDA and PA \\
\hline 27 & & University of Gothenburg & ISO 14001 + EMAS & Mix of TDA and PA \\
\hline 28 & & Umea University & ISO 14001 in process & PA \\
\hline 29 & & Swedish University of Agricultural Sciences & ISO 14001 at some departments & Mix of TDA and PA \\
\hline 42 & & Mid Sweden University & EMAS at one department & $\mathrm{n} / \mathrm{a}$ \\
\hline 43 & & University of Boras & ISO 14001 in process & $\mathrm{n} / \mathrm{a}$ \\
\hline 44 & & Mälardalen University & ISO14001 & $\mathrm{n} / \mathrm{a}$ \\
\hline 30 & United Kingdom & University of Glamorgan & ISO 14001 & TDA \\
\hline 31 & & Leeds Metropolitan University & ISO 14001 & TDA \\
\hline 32 & & Nottingham Trent University & EcoCampus & Mix of TDA and PA \\
\hline 33 & & University of Plymouth & ISO 14001 & TDA \\
\hline 45 & & University of Gloucestershire & ISO 14001 & $\mathrm{n} / \mathrm{a}$ \\
\hline 46 & & University of Leeds & Similar to ISO 14001 & $\mathrm{n} / \mathrm{a}$ \\
\hline 34 & Switzerland (non EU) & École Polytechnique Fédérale de Lausanne (EPFL) & RUMBA & No data \\
\hline 35 & & ETH - Swiss Federal Institute of Technology Zurich & ISO $14001+$ RUMBA & TDA \\
\hline 37 & France & University of Bordeaux & EcoCampus & $\mathrm{n} / \mathrm{a}$ \\
\hline 40 & & Brandenburg University of Technology Cottbus & EMAS & $\mathrm{n} / \mathrm{a}$ \\
\hline 41 & Luxembourg & University of Luxembourg & Non-formal EMS in process & $\mathrm{n} / \mathrm{a}$ \\
\hline 47 & Norway (non EU) & Norwegian University of Life Sciences) & ISO 14001 & $\mathrm{n} / \mathrm{a}$ \\
\hline
\end{tabular}

a PA: Participatory approach.

b TDA: Top-down approach.

certification process (57\%). Within the EMAS certification, for example, a new validation is requested regularly (for EMAS II every three, for EMAS III every four years). $54 \%$ of the institutions (i.e. $34 \%$ and $20 \%$ ) use sustainability reports, but only seven universities (20\%) indicated that they follow the Global Reporting Initiative (GRI) Guidelines within their reports. One institution opted for an environmental report.

\section{Discussion}

5.1. EMS at the campus as a key tool to enhance sustainable practices and participation?

A general increase of EMS implementation in universities can be registered, when comparing the results of this research (47 higher education institutions in Europe) to previous international studies (14 higher education institutions worldwide to have an EMS in 2006 (Velazquez et al., 2006); 10 institutions with ISO 14001
(Tauchen and Brandli, 2006)). The fact that five universities were at the time of this study in an EMS implementation process can be seen as a supportive sign of this trend.

As shown in Fig. 3, there is a geographical trend within the spread of the different EMS types, which corresponds to realities of EMS implementations observed in companies (Steger, 2000; Wätzold, 2009), where ISO 14001 is more dominant in Northern Europe, while EMAS is more employed in Western Europe. In contrast to Clarke and Kouri (2009), who state in their study about Canadian and New Zealand universities that most universities pursue non-formal EMS and are not seeking certification, in this research it was found out that in European universities formal EMS, such as ISO 14001 and EMAS, are more present than non-formal EMS (81\% compared to $19 \%$ ).

In this study, Social and environmental awareness/responsibility was on average the most important driver to implement a campus EMS and can be related to the third generation drivers (Bennet and James 1999; Clarke and Kouri, 2009) described in Section 2, which 
Table 2

Relation of the institution's size and type of EMS chosen.

\begin{tabular}{|c|c|c|c|c|c|c|c|}
\hline & \multicolumn{6}{|c|}{ Size of the institution (number of students enrolled) } & \multirow{3}{*}{$\begin{array}{l}\text { Total } \\
(N)\end{array}$} \\
\hline & \multicolumn{2}{|c|}{$<10000$ students (small) } & \multicolumn{2}{|c|}{ 10001-20000 students (medium) } & \multicolumn{2}{|c|}{$>20000$ students (large) } & \\
\hline & $(N)$ & $\%$ & $(N)$ & $\%$ & $(N)$ & $\%$ & \\
\hline Non-formal EMS & 3 & 37.5 & 1 & 12.5 & 4 & 50.0 & 8 \\
\hline ISO 14001 & 5 & 31.3 & 5 & 31.3 & 6 & 37.5 & 16 \\
\hline EMAS & 10 & 58.8 & 3 & 17.6 & 4 & 23.5 & 17 \\
\hline ISO 14001 \& Non-formal EMS & 0 & 0 & 1 & 100 & 0 & 0 & 1 \\
\hline ISO 14001 \& EMAS & 1 & 20.0 & 2 & 40.0 & 2 & 40.0 & 5 \\
\hline Total $(N)$ & 19 & 40.4 & 12 & 25.5 & 16 & 34.0 & 47 \\
\hline
\end{tabular}

${ }^{\text {a }}$ Non-formal EMS in this study: EcoCampus, Oficina EcoCampus, RUMBA, EMS following a similar structure of ISO 14001 or EMAS.

refer to the leadership function a university has regarding the promotion of sustainable development (Section 1.1).

The study demonstrates that EMAS was mainly implemented via a participatory approach, whereas ISO 14001 was implemented almost equally by a participatory, a top-down and a mix of both approaches (Fig. 4). These results align with the specific characteristics of each EMS: ISO 14001 is considered to be more flexible than EMAS, and therefore any of the approaches can be appropriate. EMAS, instead, includes as a requisite the involvement of the community (in enterprises, the employees; in a university context, students and staff).

As underlined in the literature, campus sustainability should follow an integrative approach (Alshuwaikait and Abubakar, 2008) that is based on three pillars, which are the implementation of an EMS, public participation and sustainability teaching. The high number of certified EMS and the relatively high degree of participation of universities in this study can be seen as a reflection of this integrated approach. However, only 11 universities indicated to have linked the campus EMS to the curriculum related activities (Fig. 5). This does not necessarily mean that the universities do not have further curricular activities related to sustainable development, but taking into account the literature on this topic (Lidgren et al., 2006; Lozano, 2010), it can be concluded that there is still a lot of potential to revise and to green the curriculum.

Even though those universities with the highest degree of participation mainly employed EMAS (Fig. 6) and a moderate relation between the degree of participation and the EMS type could be observed, it is not exclusively the EMS type itself that determines a good participatory performance. It is up to universities to shape the implementation process, but an integrative approach appears to make up grade best with the university's twofold mission regarding sustainable development stated in the

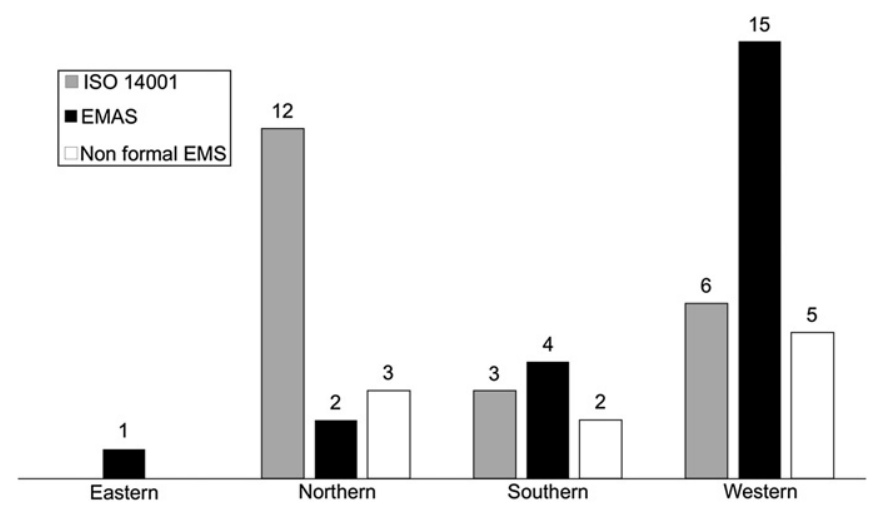

Fig. 3. Frequency of EMAS, ISO 14001 and non-formal EMS at European universities per sub region ( $N=47$ universities, three institutions have more than one system implemented). introduction. A top-down approach may be less time consuming, more focused on the improvement of operational environmental performance and oriented towards compliance with regulations and administrative requirements, whereas a participatory approach applies a more systemic perspective that allows to develop new teaching and learning settings. While being more resource-intensive regarding time and staff, a participatory approach focuses on empowerment, combining the provision of technical and analytical skills with the creation of understanding and awareness in order to achieve not only a better environmental performance, but a better incorporation of sustainable development taken as a whole.

An effective and efficient implementation of sustainable development requires an overall paradigm shift within all dimensions of a university system that have initially been identified by Cortese (2003) and completed by Lozano (2006). Linking an EMS to the question of community participation and involvement, an EMS cannot result only in operational improvements (campus operations), but also develop further the discussion about revising the curriculum towards sustainability (education), point out new investigation fields (research) and enhance the collaboration with internal and the communication with external stakeholders, e.g. new students, parents, future employers (external community). As per definition EMS require continuous improvement, they can help institutions to measure and to communicate their achievements, i.e. to periodically execute assessments and to regularly publish reports (assessment and reporting). With regard to the latter dimension, the results of this study show that the majority of the participating institutions appear to have included both aspects, since $60 \%$ carry out regular audits and $57 \%$ elaborate sustainability reports (Fig. 7). However, sustainability reporting in universities is not a common practice yet when compared to corporations

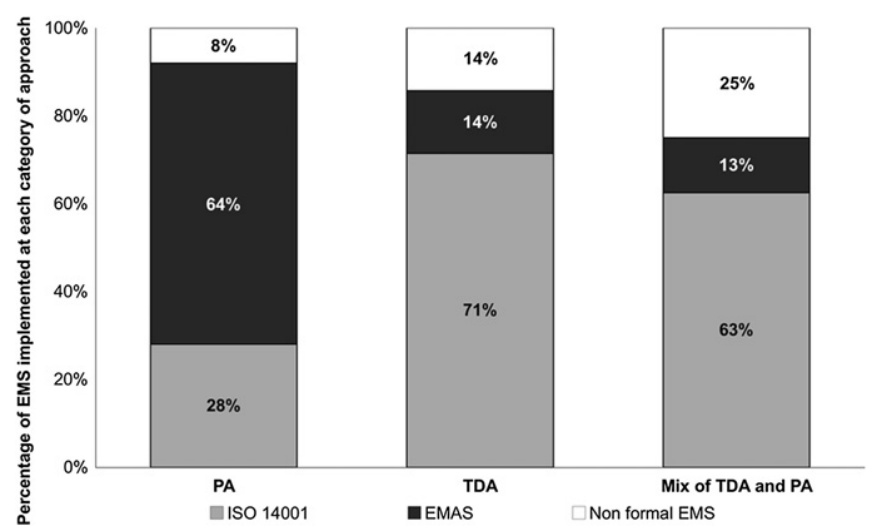

Fig. 4. Percentage of EMS types per implementation approach $(\mathrm{PA}=$ Participatory approach, TDA $=$ Top-down approach). 


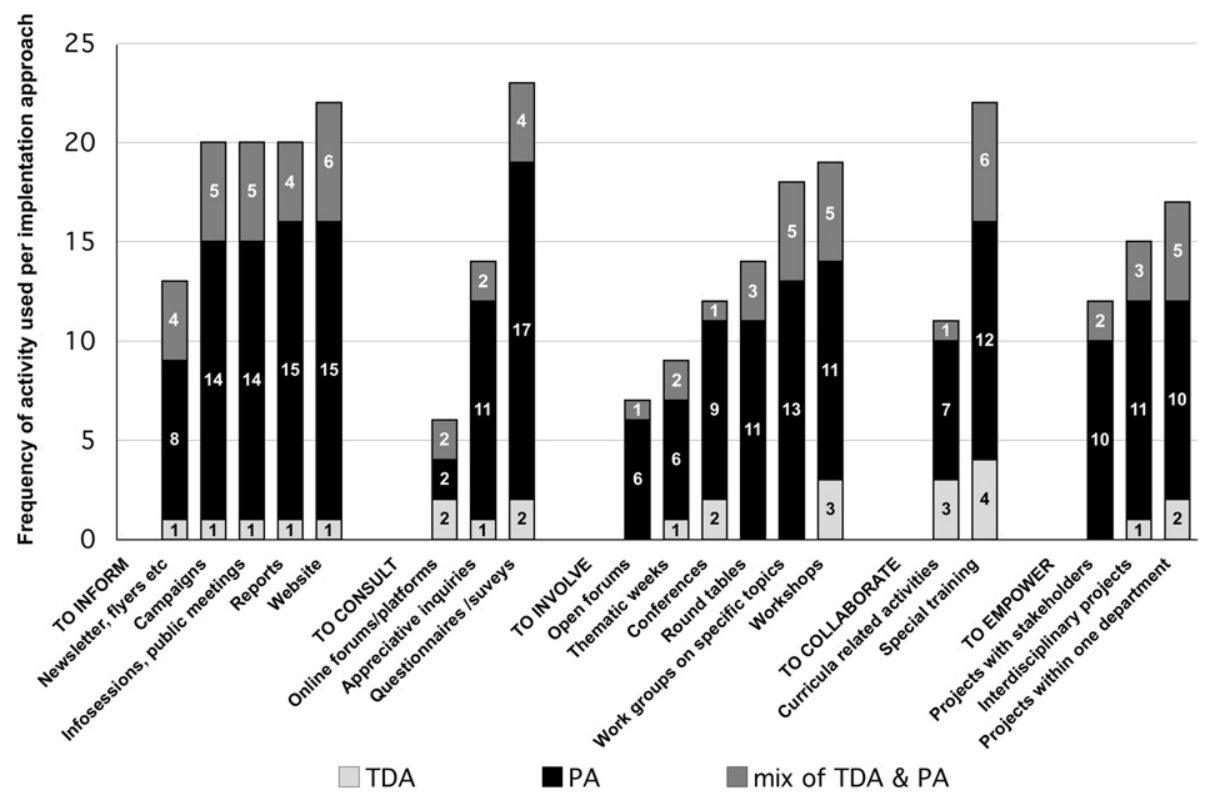

Fig. 5. Participation levels - Activities and methodologies used according to the participation level and the approach followed.

(Fonseca et al., 2011), and information about the social and educational dimension is often underrepresented (Lozano, 2011).

Through the results of this study, it was not only shown that (i) EMS can work in the university context, but that (ii) EMS at the campus can be used in a broader sense, beyond operational aspects, combining it with sustainability teaching and participation methods. The assumption that an EMS can enhance sustainable practices and participation, can be supported, as an EMS offers manifold possibilities to give students, faculty and staff the opportunity to put sustainability into practice (Fig. 5). Nevertheless, the potentials for participation seem to have not been fully explored, as activities and methodologies on a higher participation level have been less frequently applied.

\subsection{Campus EMS and competencies for sustainable development - implications for practitioners}

In the following, we raise a link between competencies for sustainable development, international exchange activities and students' employability, in order to show possibilities how a campus EMS can be used beyond the campus itself for international participation and cooperation.

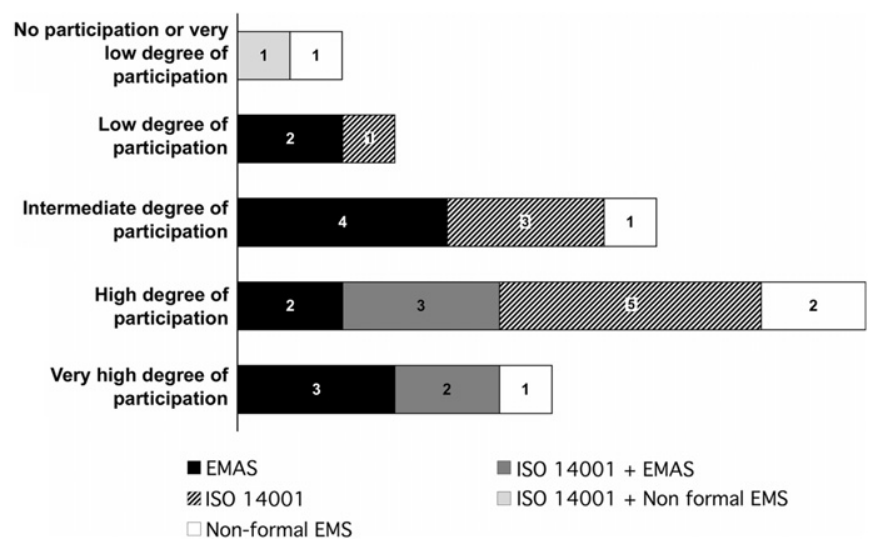

Fig. 6. Degree of participation related to the EMS type implemented.
Internationalization and partnerships among universities are one of the core focuses of today's university developments and are given high attention (Altbach and Knight, 2007). Academic international exchange activities started in the 80 s and are an important pillar of academic activity, institutional presence and academia evaluation (internationalization as an indicator of quality performance). Most universities have an international relations office to coordinate the activities and to develop further partnerships and cooperation. It is seen as a win-win situation for the engaged institutions and students. In general, international exchange activities aim to develop students' intercultural skills, their selfreliance and self-awareness, and to strengthen the relationships between institutions and countries.

Education for sustainable development encompasses a number of key competencies, that have been defined to be (i) competencies in foresighted thinking; (ii) competency in interdisciplinary work; (iii) competency in cosmopolitan perception, cross-cultural understanding and cooperation; (iv) participatory skills; (v) competency in planning and implementation; (vi) capacity for empathy, compassion and solidarity; (vii) competency in self-motivation and in motivation others; (viii) competency in distanced reflection on individual and cultural models (de Haan, 2006).

The objectives of international exchange activities are in line with the listed key competencies for sustainable development, and there are diverse opportunities to use an EMS at the campus to combine sustainability teaching and international exchange. Exchange activities in the sustainability field, for example, with EMS related activities, could be one of many options, as an EMS is engaged with a wide spectrum of academic areas (management, engineering, social science, education, to name a few). Student and staff exchange could not only support the development of the competencies listed above, but also help the institutions and their communities to learn from each other and to develop a better understanding about practical issues of a sustainable campus. Student awards, international competitions about the institution's carbon footprint, international weeks or summer programmes are some suggestions that could stimulate activities in this field and promote campus sustainability beyond the local limits. These types of activities would give the parties involved valuable international experiences and a broader understanding of sustainable development. It may also 


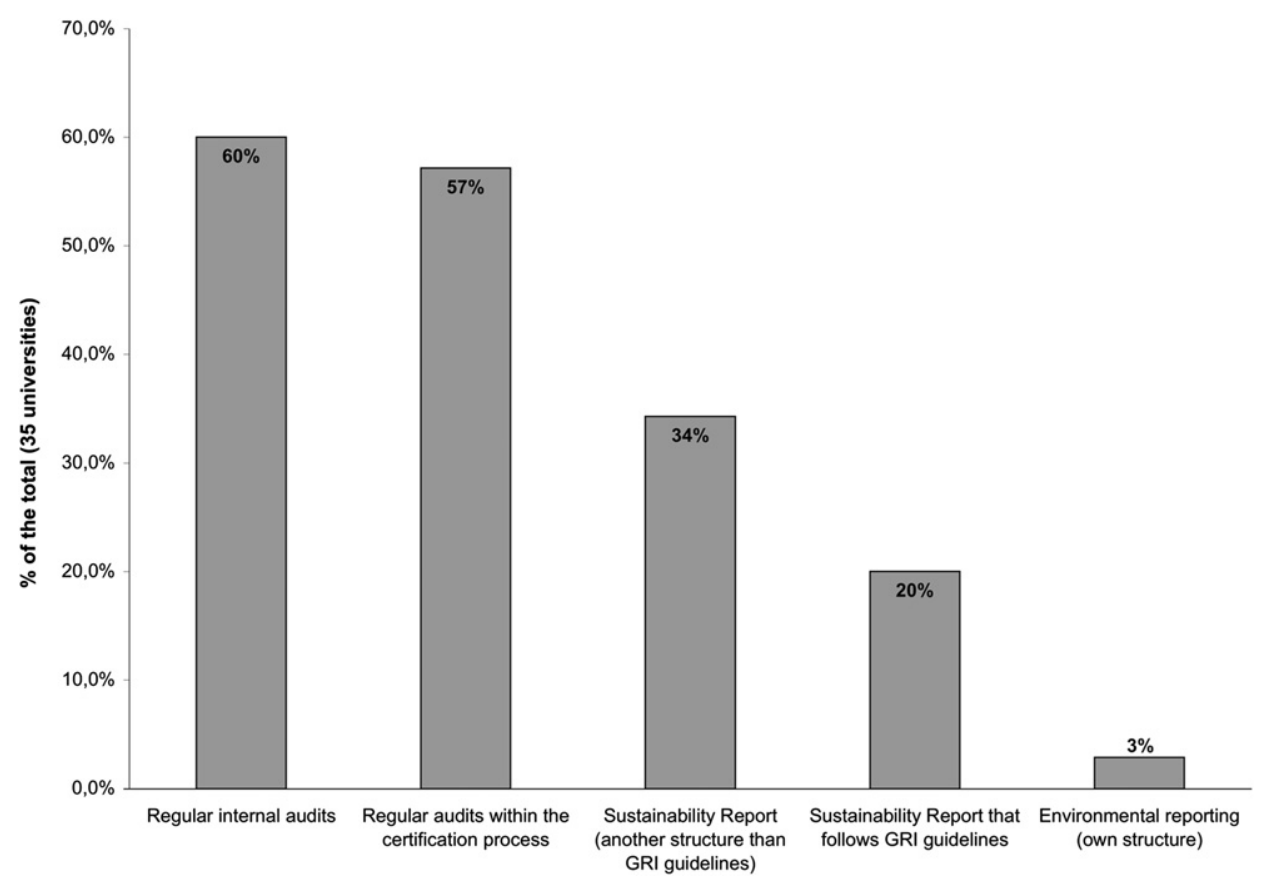

Fig. 7. Measurement and reporting tools applied.

have a positive impact on students' employability, as these experiences will equip them better for new demands in the labour market, and allow them to contribute constructively to sustainable-minded solutions or even to initiate new solution strategies they might apply in their professional life.

It would be desirable that political authorities and board members of universities pay a similar attention to sustainable development in higher education institutions as for internationalization issues. Even though today an increasing number of universities pursue staff exclusively for environmental and sustainability issues, it is not a well-established reality yet compared to the existence of International Relations Offices. It is time that competencies for sustainable development are included as a priority of universities, given a similar regard as intercultural skills and cross-cultural awareness, as in the end these are transversal skills linked together. We can register progress in this field; however, a broad focus on sustainable development is still missing in most of higher education institutions.

\section{Conclusion}

Campus sustainability is receiving growing attention and has become a well-established study field, even though campus sustainability itself has not become a reality yet in most universities.

We see an EMS as one tool in the overall process to enhance campus sustainability. With respect to the implementation of an EMS at the campus, we regard a participatory or a mix of top-down and participatory approach as most effective to accomplish the twofold mission of a university stated in our introduction: (1) To reduce the institutional environmental impact and (2) to carry out research and teaching, offering opportunities to increase awareness for complex coherences and to develop competencies that lead to more sustainable practices.

If an EMS is implemented only by a top-down process, it may achieve environmental improvements within the universities' operations, but it would exclude the educational aspect of campus sustainability. Only in combination with participation, the EMS can be a powerful supportive tool not only for improving operational environmental performance, but for creating the necessary settings that allow a paradigm shift to sustainable practices within all dimensions of a university system. It can bring forward the discussion about campus sustainability and increase the understanding as well as the internal and external collaboration between all stakeholders of a university system. Even though EMS can therefore be considered an important tool among sustainability initiatives, the success, effectiveness and visibility of any action undertaken would depend on each institution's vision, effort and resources.

A frequently reported barrier to campus greening has been the overall lack of awareness from students, faculty and staff. By offering hands-on approaches to tackle complex problems, the situation can be reversed. With regard to the global challenges and expected changes in the job markets, it is particularly essential to prepare the students in the best way for the needs we are confronted with and to involve them in establishing new sustainable strategies. EMS at the campus can help offering these practical learning experiences, and we hope that this paper may be a useful source of reflection and guideline for higher education institutions that either already pursue an EMS or that are considering to start an implementation process.

Campus sustainability and particularly the field of campus EMS are emerging research areas. Clarke and Kouri (2009) listed several research requests for further international comparisons of campus EMS, e.g. empirical investigation on different structures and processes of an EMS and on staff responsibilities. Other aspects for future research may be: (i) economic, environmental, and social benefits of an EMS at the campus (e.g. assessment of the consumption of resources, level of awareness of the community); (ii) institutional changes due to the EMS process (e.g. related to the incorporation and institutionalization process of sustainable development in universities); (iii) further environmental management tools and sustainability indicators (e.g. that refer to Corporate Social Responsibility and Governance); (iv) exploration of further assessment and reporting tools for sustainability at campuses (e.g. GASU, AISHE, Sustainability Report Card, STARS) and how these are applied. 
With regard to participatory processes, future research is needed to develop assessment tools for participatory processes in order to measure their effectiveness and success, helping to answer questions like "Does a high participation mean an effective sustainable campus"? Research about the contribution of participatory processes to students' maturity, personal development and the overall development of key competencies for sustainable development of the university's community's members (students, faculty and staff) is still underexplored.

\section{Acknowledgements}

We would like to thank all survey respondents for providing information about the EMS in their universities and for sharing their valuable experience. The lead author would like to express her gratitude to Mr. Reinhard Peglau from the German Federal Environmental Agency for his helpful collaboration.

\section{References}

Adomssent, M., Godemann, J., Michelsen, G., 2008. Sustainable University Empirical evidence and strategic recommendations for holistic transformation approaches to sustainability in higher education institutions. In: Proceedings of the 4th International Barcelona Conference on Higher Education. Higher Education for Sustainable Development. Barcelona. Available online: http:// www.guni-rmies.net (Retrieved 20.11.11).

Alshuwaikait, H.M., Abubakar, I., 2008. An integrated approach to achieving campus sustainability: assessment of the current campus environmental management practices. Journal of Cleaner Production 16, 1777-1785.

Altbach, P.G., Knight, J., 2007. The internationalization of higher education: motivations and realities. Journal of Studies in International Education 11, 290-305.

Arvidsson, K., 2004. Environmental management at Swedish universities. International Journal of Sustainability in Higher Education 5 (1), 91-99.

Bakker, D., 1998. In Search of Green Campuses: An Investigation of Canadian Universities' Environmental Initiatives and Implications for Dalhouise University. Dalhouise University, Halifax.

Bennet, M., James, P. (Eds.), 1999. Sustainability Measures: Evaluating and Reporting on Social and Environmental Performance. Greenleaf Publishing Ltd, Sheffield, UK.

Carreiras M, Ferreira A.J.D., Lopes M., Castanheira E., 2006. Comparison between Two Implementation Strategies of Environmental Systems. Paper Presented at the Quest for Sustainability. The role of Environmental Management Systems and Tools. Coimbra. Available online: http://www.esac.pt/emas@school/ Publicacoes/Comunicacoes/quest_coimbra/t2.pdf (Retrieved 10.05.10).

Čiegis, R., Gineitiene, D., 2006. The role of universities in promoting sustainability. Universitetụ vaidmuo skatinant darnụji vystymąsi 48 (3), 56-62.

Chambers, D., 2009. Assessing \& planning for environmental sustainability - A framework for institutions of higher education. In: Filho, W.L. (Ed.), Sustainability at Universities - Opportunities, Challenges and Trends. Peter Lang, Frankfurt.

Clarke, A., Kouri, R., 2009. Choosing an appropriate university or college environmental management system. Journal of Cleaner Production 17, 971-984.

Conger, J.A., Kanungo, R.N., 1988. The empowerment process: integrating theory and practice. Academy of Management Review 13 (3), 471-482.

Copernicus Alliance, 2010. Copernicus Charta. Available online: http://www2. leuphana.de/copernicus/index.php?id=3 (Retrieved 07.08.10).

Cortese, A.D., 1999. The University as a Model for Sustainability. Second Nature Education for Sustainability, pp. 1-4.

Cortese, A.D., 2003. The critical role of higher education in creating a sustainable future. Planning for Higher Education. Available online: http://www.aashe.org documents/resources/pdf/Cortese_PHE.pdf (Retrieved 02.11.11).

Dahle, M., Neumayer, E., 2001. Overcoming barriers to campus greening - A survey among higher educational institutions in London. International Journal for Sustainability in Higher Education 2 (2), 139-160.

de Haan, G., 2006. The BLK '21' programme in Germany: a 'Gestaltungskompetenz' based model for education for sustainable development. Environmental Education Research 12 (1), 19-32.

Delakowitz, B., Hoffmann, A., 2000. The Hochschule Zittau/Goerlitz: Germany's first registered environmental management (EMAS) at an institution of highe education. International Journal for Sustainability in Higher Education 1 (1), 35-47.

European Comission, 2011a. Overview EMAS Across the Years. Available online: http://ec.europa.eu/environment/emas/pictures/Stats/2011-06_Overview_of_ the_take-up_of_EMAS_across_the_years.jpg (Retrieved 21.08.11).

European Comission, 2011b. Overview EMAS in the Participating Countries. Available online: http://ec.europa.eu/environment/emas/pictures/Stats/2011-06_ Overview_of_the_take-up_of_EMAS_in_the_participating_countries.jpg (Retrieved 21.08.11).
Evangelinos, K.I., Jones, N., Panoriou, E.M., 2009. Challenges and opportunities for sustainability in regional universities: a case study in Mytilene, Greece. Journal of Cleaner Production 17, 1154-1161.

Ferreira, A.J.D., Lopes, M.A.R., Morais, J.P.F., 2006. Environmental management and audit schemes implementation as an educational tool for sustainability. Journal of Cleaner Production 14, 973-982.

Ferrer-Balas, D., Buckland, H., de Mingo, M., 2009. Explorations on the University's role in society for sustainable development through a system transition approach. Case-study of the Technical University of Catalunia (UPC). Journal of Cleaner Production 17, 1075-1085.

Florin, P., Wandersman, A., 1990. An introduction to citizen participation, voluntary organizations, and community development: Insights for empowerment through research. American Journal of Community Psychology 18 (1), 41-54.

Fonseca, A., Macdonald, A., Dandy, E., Valenti, P., 2011. The state of sustainability reporting at Canadian universities. International Journal for Sustainability in Higher Education 12 (1), 22-40.

Fowler, F.J.J., 2002. Survey Research Methods. SAGE Publications, Thousand Oaks.

Hansen, J.A., Lehmann, M., 2006. Agents of change: universities as development hubs. Journal of Cleaner Production 14 (9-11), 820-829.

Harvey, L., 2000. New realities: the relationship between higher education and employment. Tertiary Education and Management 6 (1), 3-17.

Helling, K., Cosack T., 2007. Zero-Emission-Campus. Successes and experiences of the Environmental Campus Birkenfeld. Paper Presented at the Sustainable Campus Conference. Zurich. Available online: http://www.internationalsustainable-campus-network.org/fileadmin/downloads/Panel_A1_Klaus_ Helling.pdf (Retrieved 02 Feb 2011).

Hill, M.M., Hill, A., 2009. Investigação por questionário, second ed. Edições Sílabo, Lisbon.

Holyoak, L., 2001. Participation and empowerment in organizations: modeling, effectiveness and applications. Leadership \& Organization Development Journal 22 (3), 139-142

Howell, R.E., Olsen, M.E., Olsen, D., 1987. Designing a Citizen Involvement Program: A Guidebook for Involving Citizens in the Resolution of Environmental Issues. Western Rural Development Center.

International Association for Public Participation, 2007. Spectrum of Public Participation. Available online: http://www.iap2.org/associations/4748/files/IAP2\% 20Spectrum_vertical.pdf (Retrieved 27.01.11).

ISO Central Secretariat, 2011. The ISO Survey - 2009. ISO Central Secretariat, Geneva. Available online: http://www.iso.org/iso/survey2009.pdf (Retrieved 22.08.11).

Koester, R.J., Eflin, J., Vann, J., 2006. Greening the campus: a whole systems approach. Journal of Cleaner Production 14 (9-11), 769-779.

Leal Filho, W. (Ed.), 2009. Sustainability at Universities - Opportunities, Challenges and Trends, vol. 31. Peter Lang, Frankfurt.

Lidgren, A., Rodhe, H., Huisingh, D., 2006. A systemic approach to incorporate sustainability into university courses and curricula. Journal of Cleaner Production 14 (9-11), 797-809. doi:10.1016/j.jclepro.2005.12.011.

Lozano, R., 2006. Incorporation and institutionalization of SD into universities: breaking through barriers to change. Journal of Cleaner Production 14 (9-11), 787-796.

Lozano, R., 2010. Diffusion of sustainable development in universities curricula: an empirical example from Cardiff University. Journal of Cleaner Production 18 (10), 637-644.

Lozano, R., 2011. The state of sustainability reporting in universities. International Journal for Sustainability in Higher Education 12 (1), 67-78.

Lozano Garcia, F.J., Kevany, K., Huisingh, D., 2006. Sustainability in higher education: what is happening? Journal of Cleaner Production 14 (9-11), 757-760.

Lukman, R., Glavic, P., 2007. What are the key elements of a sustainable university. Clean Technology \& Environmental Policy 9, 103-114.

Meadowcroft, J., 2004. Participation and Sustainable Development - modes of citizen, community and organisational involvement. In: Lafferty, W.M. (Ed.), Governance for Sustainable Development - The Challenge of Adapting Form to Function. Edward Elgar Publishing, Inc., Northampton, pp. $162-190$.

Nicolaides, A., 2006. The implementation of environmental management - Towards sustainable universities and education for sustainable development as an ethical imperative. International Journal of Sustainability in Higher Education 7 (4), 414-424.

Noeke, J., 2000. Environmental Management Systems for universities - A case study. International Journal of Sustainability in Higher Education 1 (3), 237-251.

OECD, 2001. Citizens as partners - OECD handbook on information, consultation and public participation in policy-making. In: OECD (Ed.), Governance. Available from: http://www.ezd.si/fileadmin/doc/4_AKTIVNO_DRZAVLJANSTVO/ Viri/Citizens_as_partners_hanbook_oecd.pdf.

Oelreich, K.V., 2004. Environmental certification at Maelardalen University. International Journal for Sustainability in Higher Education 5 (2), 133-146.

Sammalisto, K., Brorson, T., 2008. Training and communication in the implementation of Environmental Management Systems (ISO 14001): a case study at the University of Gaevle, Sweden. Journal of Cleaner Production 16, 299-309.

Savely, S.M., Carson, A.I., Declos, G.L., 2007. A survey of the implementation status of Environmental Management Systems in U.S. colleges and universities. Journal of Cleaner Production 15 (7), 650-659.

Sharp, L., 2002. Green campuses: the road from little victories to systemic transformation. International Journal of Sustainability in Higher Education 3(2), 128-145. 
Simkins, G., Nolan, A., 2004. Environmental Management Systems in Universities. Available online: http://www.eauc.org.uk/environmental_management_systems_ in_universities_a (Retrieved 17.05.10).

Steger, U., 2000. Environmental Management Systems: empirical evidence and further perspectives. European Management Journal 18 (1), 23-37. doi:10.1016 S0263-2373(99)00066-3].

Tashakkori, A., Teddlie, C., 1998. Mixed Methodology - Combining Qualitative and Quantitative Approaches. SAGE Publications, Thousand Oaks.

Tauchen, J., Brandli, L.L., 2006. A Gestão Ambiental em Instituições de Ensino Superior: Modelo para implantação em campus universitário. Gestão \& Produção 13 (3), 503-515.

ULSF, 2008. Talloires Declaration. Available online: http://www.ulsf.org/about.html (Retrieved 19.02.11).

UNCED, 1992. Agenda 21, Ch. 36: Promoting Education and Public Awareness and Training. Rio de Janeiro: United Nations.

UNECE, 2001. Aarhus Convention - Convention on Access to Information, Public Participation in Decision-Making and Access to Justice in Environmental Matters. Available online: http://www.unece.org/env/pp/ (Retrieved 20.02.11).

UNEP, 1972. Declaration of the United Nations Conference on the Human Environment. United Nations Conference on the Human Environment, Stockholm. Available online: http://www.unep.org/Documents.Multilingual/Default.asp? documentid=97\&articleid=1503 (Retrieved 25 Aug 2010).
UNESCO, 1977. Tbilisi Declaration - Final Report. Intergovernmental Conference on Environmental Education, Tbilisi. Available online: http://unesdoc.unesco.org images/0003/000327/032763eo.pdf (Retrieved 25 Aug 2010).

UNESCO, 2010. UN Decade of Education for Sustainable Development Education. Available online: http://www.unesco.org/en/education-for-sustainabledevelopment/decade-of-esd/ (Retrieved 20.02.11).

United Nations Statistic Division, 2010, 17-02-2011. Composition of Macro Geographical (Continental) Regions, Geographical Sub-regions, and Selected Economic Groupings. Available online: http://unstats.un.org/unsd/methods/ m49/m49regin.htm\#europe (Retrieved 01.03.11).

Velazquez, L., Munguia, N., Platt, A., Taddei, J., 2006. Sustainable university: what can be the matter. Journal of Cleaner Production 14 (9-11), 810-819.

Viebahn, P., 2002. An environmental management model for universities - from environmental guidelines to staff involvement. Journal of Cleaner Production 10 (1), 3-12.

Wätzold, F., 2009. Explaining differences in EMAS participation rates across Europe: the importance of institutions, incomplete information and path dependence. European Journal of Law and Economics 28 (1), 67.

Weenen van, H., 2000. Towards a vision of a sustainable university. International Journal of Sustainability in Higher Education 1 (1), 20-34.

Zutshi, A., Sohal, A., 2005. Integrated management system: the experience of three Australian Organisations. Journal of Manufacturing Technology Management 16 (2), 211-232. 